\title{
PENERAPAN MANAJEMEN BERBASIS SEKOLAH DI MADRASAH (ALTERNATIF PENINGKATAN MUTU PENDIDIKAN MADRASAH)
}

\section{Muh Anwar}

Universitas Islam Negeri Alauddin Makassar Sulawesi Selatan, Indonesia

Email: hm77.anwar@gmail.com

\begin{tabular}{ll}
\hline INFO ARTIKEL & ABSTRAK \\
\hline Diterima & Tulisan ini adalah mengungkap masalah inti yang di Madrasah \\
25 Juli 2021 & sebagai penghambat dalam peningkatan mutu madrasah. Hasil \\
Direvisi & kajian menunjukkan bahwa Madrasah diperhadapkan \\
05 Agustus 2021 & dengannmasalah yang dilematis sebagai lembaga \\
Disetujui & pendidikan. Sebagai lembaga pendidikan semestinya \\
15 Agustus 2021 & Madarasah kewenangan yang diberikan secara luas untuk \\
\hline Kata Kunci: & pengelolaan madrasah, terlebih saat ini adalah era otonomi \\
manajemen; mutu; & daerah. Konsep yang dapat diterapkan pada era otonomi saat \\
madrasah & ini salah satunya untuk meningkatkan mutu pendidikan adalah \\
& dengan Manajemen berbasis sekolah. Strategi untuk \\
& mewujudkan sekolah menjadi lebih bermutu dengan \\
& memberikan kewenangan yang luas kepada Madrasah adalah \\
& MBS. Meskipun Madrasah berada di bawah naungan \\
& Departemen Agama, namun konsep MBS tetap dapat \\
& diterapkan berdasarkan atas kecocokan MBS sebagai strategi \\
& mengatasi masalah Madrasah.
\end{tabular}

\section{ABSTRACT}

This paper aims to reveal the core problems in Madrasahs as obstacles in improving the quality of madrasas. The results of the study show that Madrasahs are faced with a dilemmatic position as educational institutions. As an educational institution, madrasas should be given broad authority in the management of madrasas, especially when this is the era of regional autonomy. In the current era of autonomy, one of the concepts that can be applied to improve the quality of education is school-based management. SBM is a strategy to make schools become more qualified by giving broad authority to Madrasahs. Although Madrasahs are under the auspices of Keywords: $\quad$ the Ministry of Religion, the SBM concept can still be applied management; $\quad$ based on the suitability of SBM as a strategy to address quality; madrasah Madrasah problems.

$\begin{array}{ll}\text { How to cite: } & \text { Anwar, M. (2021) Penerapan Manajemen Berbasis Sekolah di Madrasah (Alternatif Peningkatan } \\ & \text { Mutu Pendidikan Madrasah). Jurnal Syntax Admiration 2(8). https://doi.org/10.46799/jsa.v2i8.290 } \\ \text { E-ISSN: } & 2722-5356 \\ \text { Published by: } & \text { Ridwan Institute }\end{array}$




\section{Pendahuluan}

Permasalahan Tingkat pendidikan yang dihadapi bangsa Indonesia saat ini sangat rendah kualitas beragam institusi pendidikan, seperti institusi pendidikan Islam sebagai madrasah. Usaha tertera dilandasi oleh kesadaran akan semakin pentingnya pendidikan selama peningkatan sumber daya manusia serta pembangunan karakter umat.

Kualitas pendidikan di indonesia dianggap oleh banyak kalangan yang masih rendah dan Ada 4.444 alasan yang disebabkan oleh peningkatan kualitas pendidikan Islam, tetapi tidak banyak berubah (Firdianti, 2018). Kemungkinan kendala rendahnya kualitas pendidikan Islam di Indonesia, pertama-tama, pendidikan tidak memperhatikan semua tahapan prosesnya. sedangkan, metode pendidikan ditentukan oleh karakter produksi/keluaran yang ada.

Kedua, pembangunan pendidikan Islam yang terkonsentrasi membuat kualitas pendidikan sangat tergantung pada pilihan dan strategi yang dikeluarkan bukan bertemu serta suasana yang ada. Sekolah Islam bertambah seperti semacam subordinasi, sehingga dapat menghilangkan motivasi, kreativitas dan inisiatif dari pembangunan dan kemajuan, tercantum menaikkan karakter pendidikan seperti satunya yaitu alamat pendidikan nasional.

Ketiga, adanya ketidakharmonisan antara lembaga pendidikan Islam, khususnya sekolah Islam atas masyarakat sekitar lingkungan sekolah. semasa ini fungsi warga sekolah khususnya guru dan fungsi bersama masyarakat khususnya orang tua siswa dalam penyusunan pendidikan masih kurang. Selain itu, keputusan guru sewaktu-waktu diabaikan, yang dapat mengakibatkan kerjasama masyarakat yang lebih luas terbatas pada dukungan keuangan. Oleh karena itu, seolah-olah tidak ada ikatan imbang balik antara lembaga pendidikan dan masyarakat.

Sekolah dasar Juga mempunyai tanggung jawab dan fungsi melayani masyarakat, selain itu sekolah juga dianggap sebagai suatu sistem sosial karena tersusun dari rangkaian unsur dan kegiatan yang saling mempengaruhi dan membentuk kekuatan sosial (Hasanah et al., 2010).

Menurut ketentuan Undang-Undang Otonomi Daerah No. 22 Tahun 1999, masalah-masalah tersebut di atas seharusnya sudah diselesaikan. Otoritas hukum dapat memberikan beberapa langkah solusi untuk banyak orang di madrasah. Sekolah agama yang dapat dijadikan lembaga pendidikan masih berpengaruh di bawah Kementerian Agama, dan bentuk pusatnya seolah meniadakan undang-undang otonomi daerah. Menjadi.

Artikel ini bertujuan untuk mengkaji rancangan administrasi mutu di madrasah untuk meluaskan mutu pendidikan di madrasah. Sangat menarik untuk membahas bagaimana meningkatkan kualitas pendidikan di madrasah. Oleh karena itu, artikel ini juga mencoba menguji peluang madrasah mampu menerapkan manajemen mutu sekolah menjadi salah satu seleksi penambahan mutu pendidikan di madrasah. 


\section{Metode Penelitian}

Penelitian yang memiliki penelitian kualitatif adalah penelitian yang dilakukan dengan cara mengamati, dan dilakukan pada latar alamiah atau konteks keseluruhan, dan alat pengumpulan data utama adalah penelitian sendiri. Sumber data dalam penelitian ini adalah: beberapa sekolah madrasah di Kabupaten Gowa dan Kota Makassar. Data yang akan dikumpulkan berkaitan dengan kajian penerapan manajemen berbasis sekolah di Madrasah dalam meningkatkan mutu pendidikan adalah sebagai berikut: 1) Kewenangan dan Otonomi Institusi Sekolah Yang Jelas. 2) Praktek Kepemimpinan Demokratis dan Pengambilan Keputusan Teknis yang Partisipatif di Sekolah.3) Pemberdayaan prasarana Pendidikan yang Efektif bermutu Mendukung Program Pembelajaran. Teknik pengumpulan data dilakukan secara wawancara dan mengamati, analisis data bersifat induktif, dan hasil penelitian kualitatif lebih menekankan makna dari pada generalisasi. (Arikunto, 2010) mengemukakan bahwa dalam suatu penelitian dibutuhkan data. Dalam pengumpulan data dibutuhkan teknik, baik teknik dalam penyediaan data, maupun teknik dalam melakukan klasifikasi data yang telah dikumpulkan. Data yang telah terkumpul tidak bisa langsung disajikan dalam laporan penelitian, tetapi harus diolah dan dianalisis terlebih dahulu. Analisis data dibuat setelah data-data dan informasi-informasi yang diperoleh sesuai dengan kebutuhan disusun, digolongkan dan dirumuskan atas dasar interpretasi data. Miles dan Humberman dalam (Ramadhan \& Sugiyono, 2015) mengemukakan bahwa analisis data kualitatif merupakan upaya berlanjut, berulang dan terus menerus. Menurut mereka ada tiga tahap analisis data yaitu: reduksi data, display atau penyajian data serta pengambilan kesimpulan dan verifikasi data.

\section{Hasil dan Pembahasan}

Berdasarkan hasil penelitian diperoleh temuan melalui wawancara bahwa manajemen berbasis sekolah sudah diterapkan dalam meningatkan mutu pendidikan di Madrasah yang ada di Kabupate Gowa dan Kota Makassar, yang ditinjau dari manajemen kurikulum, manajemen kesiswaan, manajemen sarana dan prasarana pendidikan, manajemen peningkatan mutu guru. Hal ini memang merupakan keharusan dan sesuai dengan anjuran dari Kemendikbud RI bahwa proses pembelajaran disekolah harus mengacu kepada Kurikulum 2013. Kurikulum yang disusun dan direncanakan maupun diperbaharui dilakukan setiap tahun pelajaran baru. Hal ini dilakukan agar hasil dari proses pembelajaran yang sudah dilakukan yang mengacu kepada kurikulum yang ditetapkan dapat diperbaiki dan ditingkatkan mutu pembelajaran yang akan dilaksanakan.

Manajemen berbasis sekolah sudah diterapkan dalam meningkatkan mutu pendidikan di Madrasah yang ada di Kabupate Gowa dan Kota Makassar ditinjau dari manajemen sarana dan prasarana. Hal ini diketahui dari hasil wawancara dengan beberapa kepala sekolah madrasah yang mengatakan bahwa dalam mengembangkan sarana prasarana di sekolah dengan cara menggunakan dana bantuan operasional sekolah, juga melibatkan para orangtua peserta didik dan para alumni. 
Berdasarkan hasil observasi yang dilakukan penerapan manajemen berbasis sekolah dalam meningkatkan mutu pendidikan di Madrasah yang ada di Kabupate Gowa dan Kota Makassar dengan memanfaatkan dana dana bantuan operasional sekolah semaksimal mungkin, yaitu berupaya untuk melengkapi sarana prasarana yang ada, Manajemen berbasis sekolah sudah diterapkan dalam meningkatkan mutu pendidikan di Madrasah yang ada di Kabupaten Gowa dan Kota Makassar ditinjau dari manajemen peningkatan mutu guru adalah pada tahun 2019 jumlah guru yang memiliki sertifikat mendidik sebanyak 60\% orang dari jumlah 187 guru PNS yang ada di Madrasah yang ada di Kabupaten Gowa dan Kota Makassar yang dijadikan obyek penelitian, dan mengupayakan melengkapi sarana yang ada sebagai penunjang pembelajaran agar para pendidik dapat melaksanakan proses pembelajarannya dengan baik. Selain dari pada itu,

kinerja tenaga kependidikan juga sudah dianggap baik, karena didukung oleh disiplin ilmu tenaga kependidikan yang dianggap sesuai dengan tugas yang dilaksanakan. selalu memberikan motivasi kepada tenaga pendidik agar kinerja yang diharapkan benar-benar tercapai, seperti memotivasi para guru yang belum memiliki sertifikat pendidik tetap bekerja secara profesional serta menambah poin dari hasil UKG, agar pada saatnya bisa mengikuti ulang program PPG dalam jabatan.

Manajemen berbasis sekolah sudah diterapkan dalam meningkatkan mutu pendidikan di Kabupaten Gowa dan Kota Makassar ditinjau dari manajemen kesiswaan diketahui dari kegiatan yang dilakukan di madrasah secara terjadwal yaitu kegiatan upacara bendera, (untuk sementara dikarenakan keadaan maka upacara dan berbagai kegiatan untuk sementara ditiadakan) kegiatan senam pagi bagi seluruh warga sekolah dilaksanakan setiap hari Rabu, sarapan pagi bersama pada hari Jum'at sekaligus melakukan kegiatan kebersihan lingkungan sekolah. Kegiatan Sabtu Religi, dimana kegiatan ini difokuskan kepada kemampuan peserta didik yaitu membaca ayat pendek ayat suci Al-Qur'an, tausiyah, do'a bersama, pelaksanaan pembinaan bagi peserta didik dilakukan pada saat kegiatan Masa Pengenalan Lingkungan Sekolah, juga sering memberikan pembinaan bagi peserta didik dilaksanakan dengan Vidio Converence. Dalam melaksanakan pembinaan bagi peserta didik agar sesuai dengan tujuan yang diharapkan dengan cara memberikan pemahaman kepada peserta didik tentang visi, misi dan tujuan sekolah yang hendak dicapai. Karena peserta didiklah merupakan ujung tombak keberhasilan suatu negara dan pada saat gilirannya nanti akan menjadi pemimpin bangsa sebagai generasi penerus. Disamping itu juga, kepala sekolah memberikan pembinaan kepada peserta didik untuk berani tampil dalam segala hal, seperti membaca ayat pendek ayat suci Al-Qur'an yang dibacakan oleh peserta didik, berani menyampaikan Tausiyah, dan berani memimpin do'a bersama, kemudian peserta didik diberikan pembinaan agar berani dan mampu menjadi pembina apel pagi sebelum pelaksanaan proses pembelajaran berlangsung. Namun mengingat kondisi pandemi covid 19, semua kegiatan ini tidak dilakukan.

Berdasarkan hasil temuan penelitian, dokumentasi yang dapat dihimpun dalam penelitian ini adalah berupa: 1) dokumentasi poto penelitian yang berkaitan dengan wawancara guru; 2) dokumentasi poto sarana prasarana di beberapa madrasah 3) 
dokumentasi poto struktur organisasi; 4) dokumentasi poto kegiatan guru dalam mengajar; dan beberapa dokumentasi pendukung dalam melengkapi data penelitian seperti surat izin penelitian dari Universitas Islam Negeri Alauddin Makassar, surat izin penelitian dari Dinas Pendidikan Kabupaten Gowa dan Makassar, surat izin penelitian dari Madrasah tempat penelitian.

Berdasarkan kajian teoretik yang dijadikan acuan dalam penelitian ini adalah mengacu kepada Undang-Undang Nomor 32 Tahun 2004, bahwa manajemen berbasis sekolah merupakan suatu kajian yang banyak dibahas untuk mengubah sistem pendidikan di Indonesia dari sentralistik menjadi desentralistik sejak diberlakukannya menyebutkan bahwa pendidikan merupakan salah satu bidang pemerintahan yang wajib dilaksanakan oleh pemerintah daerah.

Pendidikan merupakan salah satu aspek yang sangat penting dan strategis dalam pengembangan dan peningkatan pembangunan di segala bidang termasuk di daerah, sehingga desentralisasi pendidikan dalam konteks otonomi daerah tidak bisa ditawartawar lagi dalam rangka peningkatan mutu pendidikan dan sumber daya manusia. Salah satu model desentralisasi pendidikan adalah manajemen berbasis sekolah yang bertujuan untuk meningkatkan mutu pendidikan di Indonesia (Mulyasa, 2013).

\section{Desentralisasi Pendidikan}

Berkualitas administrasi mutu pendidikan dikenal dua metode penyelenggaraan, ialah bentuk desentralisasi. berisi sistem pemusatan, seluruh benda yang berkaitan atas pengaturan pendidikan diatur oleh pemerintah pusat. sejumlah berkualitas sistem desentralisasi, berwenang penyusunan tersebut diserahkan terhadap negara daerah (HM, 2018). rencana desentralisasi ini telah diatur dalam Undang-Undang No 22 tahun 1999 tentang Otonomi Daerah. Undang-Undang No. 22 tahun 1999 tentang Otonomi Daerah Tentang kemungkinan-kemungkinan pengembangan suatu wilayah dalam suasana yang kondusif dan dalam suasana yang lebih demokratis. Pemberlakuan undang-undang tersebut menuntut adanya perubahan pengelolaan pendidikan dari yang bersifat sentralistik untuk yang lebih bersifat desentralistik (Chan \& Sam, 2007). Dengan lahirnya dan diberlakukannya UU No. 22 tahun 1999 (di revisi UU No. 32 tahun 2004), maka otonomi dan desentralisasi dalam segala bidang segera terwujud, termasuk bidang pendidikan yang kemudian dikenal dengan otonomi pendidikan. Dengan otonomi (desentralisasi) tersebut, diharapkan masing-masing daerah yang dalam hal pendidikan adalah Madrasah, bisa lebih terpacu untuk mengembangkan sumber daya manusianya agar mampu berdaya saing menghadapi perubahan yang selalu menantang terwujudnya integritas pihak lembaga pendidikan. Berbagai aspek dalam pendidikan sudah menjadi tanggungjawab pemerintah daerah. 6 Kemudian berkembang bagaimana desain pendidikan Islam dapat ditransformasikan atau diproses secara sistematis dalam masyarakat.

Desentralisasi dalam pendidikan dimaksudkan untuk meningkatkan mutu pendidikan khususnya dari segi manajeman dan pengelolaan. Ketentuan otonomi daerah yang dilandasi oleh Undang-Undang Nomor 22 dan Nomor 25 tahun 1999 sebagaimana diuraikan di atas secara otomatis telah membawa perubahan dalam 
bidang pendidikan. Pada awalnya manajemen pendidikan merupakan wewenang pusat, namun dengan berlakunya undang-undang tersebut maka kewenangan dialihkan ke daerah dalam hal ini kota atau kabupaten. Berkenaan dengan hal tersebut maka muncul berbagai pengertian tentang desentralisasi pendidikan. Menurut (Djalal, 2011), seperti dikutip (Nugroho, 2008), terdapat relasi antara desentralisasi dengan manajemen pendidikan. Desentralisasi pendidikan adalah sistem manajemen untuk mewujudkanpembangunan pendidikan yang menekankan kepada kebhinekaan. Desentralisasi pendidikan diartikan sebagai pelimpahan wewenang yang lebih luas (Riant, 2008).

Pengertian tersebut di atas mengandung prinsip subsidiaritas yaitu segala sesuatu yang telah dilakukan lembaga di bawah maka tidak perlu dilakukan lembaga di atasnya. Perlu dipahami bahwa prinsip ini bukan berarti pemerintah pusat lepas tangan dari pelaksanaan pendidikan. Desentralisasi tidak hanya mendorong pemerintah nasional membangun manajemen pendidikan yang terdesentralisasi, melainkan juga menjadi pendorong bagi daerah untuk mengembangkan manajemen pendidikan yang bermutu. Adapun yang dimaksud dengan desentralisasi manajemen pendidikan adalah pelimpahan wewenang dari pemerintah pusat kepada daerah untuk membuat keputusan manajemen dan menyusun perencanaan sendiri dalam mengatasi masalah pendidikan dengan mengacu kepada sistem pendidikan nasional. Desentralisasi pendidikan dapat diterapkan dalam beberapa tingkat dan struktur organisasi penyelenggaraan pendidikan, mulai dari tingkat pusat sampai tingkat satuan pendidikan. Sedangkan tujuan dari desentralisasi manajemen pendidikan adalah untuk meningkatkan efektifitas dan efesiensi manajemen dan kepuasan kerja pegawai melalui pemecahan masalah-masalah yang berhubungan langsung dengan daerah local.

Desentralisasi pendidikan membentuk salah satu model tata pendidikan yang membentuk sekolah menjadi proses pengutipan kesimpulan dan membentuk salah satu tenaga akan membenarkan mutu pendidikan bersama sumber daya manusia tertera profesionalitas guru yang akhirnya ini dirisaukan oleh beragam bagian baik sebagai konseptual desentralisasi pendidikan menyimpan alamat agar terpakai keterkaitan masyarakat dan sekolah serta pemerintah daerah berkualitas penyelenggaraan pendidikaan.

Desentralisasi manajemen pendidikan berusaha mengurangi campur tangan atau intervensi pejabat atau unit pusat terhadap persoalan-persoalan pendidikan yang sepatutnya dapat diputuskan dan dilaksanakan oleh unit di tataran bawah, pemerintah daerah atau masyarakat (Hidayat \& Machali, 2012).

Berdasarkan paparan di atas, inti dari diberlakukannya desentralisasi dalam pendidikan adalah untuk meningkatkan mutu pendidikan di setiap lembaga pendidikan. Berkaitan dengan peningkatan mutu pendidikan (Aziz, 2015) 76 Volume VIII, No.1, 2015 Jurnal eL-Tarbawi dalam era otonomi daerah maka beberapa hal yang perlu direkontruksi dalam pendidikan nasional adalah: pertama, upaya peningkatan mutu pendidikan dilakukan dengan menetapkan tujuan dan standar 
kompetensi pendidikan, yaitu melalui konsensus nasional antara pemerintah dengan seluruh lapisan masyarakat. Standar kompetensi yang mungkin akan berbeda antar sekolah atau antar daerah akan menghasilkan standar.

Kompetensi nasional dalam tingkatan standar minimal, normal, dan unggulan. Kedua, peningkatan efesiensi pengelolaan pendidikan mengarah pada pengelolaan pendidikan berbasis sekolah, dengan memberi kepercayaan yang lebih luas kepada sekolah untuk mengoptimalkan sumber daya yang tersedia bagi tercapainya tujuan pendidikan yang diharapkan. Ketiga, peningkatan relevansi pendidikan mengarah pada pengelolaan pendidikan berbasis masyarakat. Penigkatan peran serta orang tua dan masyarakat pada level kebijakan (pengambil keputusan) dan level operasional melalui komite sekolah. Peran komite meliputi perencanaan, implementasi, monitoring, serta evaluasi program kerja sekolah.Keempat pemerataan pelayanan pendidikan mengarah pada pendidikan yang berkeadilan. Hal ini berkenaan dengan penerapan formula pembiayaan pendidikan yang adil dan transparan.

Otonomi pendidikan memperoleh meluaskan kemampuan manajemen dan kebahagiaan kerja tenaga pendidikan beserta menciptakan satu sistem pendidikan menggunakan kebijakan-kebijakan yang aktual; sumber daya pendidikan berhasil digunakan menurut optimal; dapat menelusuri potensi lokal sebagai bertambah menang, dapat mengelola system.

Otonomi pendidikan sangat berguna sekali dalam meningkatkan kepuasan kerja tenaga pendidikan, efisien menajemen, dan juga dapat menciptakan kbijakankebijakan yang konkret dalam sistem pendidikan.dan juga dengan adanya otonomi pendidikan kita dapat mempergunakan sumber daya secara optimal dan juga dapat mengelola. Kemandirian ekolah adalah untuk meluaskan kinerjanya seorang diri, serta mengakomodasi beragam kapasitas sumber daya sekolah, yang pada keputusannya ditujukan untuk meluaskan mutu pendidikan selama wujud mutu hasil belajar para siswa.

UU No.32 tahun 2004 tentang Pemerintah Daerah, pada tanggal 15 Oktober 2004, dengan diberlakukannya undang undang tersebut UU No.22 tahun 1999 dinyatakan tidak berlaku lagi. Pemerintah Daerah berhak mengatur dan mengurus sendiri urusan pemerintahan menurut asas otonomi dan kewajiban pembantuan Apakah yg dimaksud otonomi daerah dan manfaat bagi daerah?

Dari kajian diatas, maka dapat diketahui bahwa desentralisasi pendidikan dengan maksud untuk meluaskan pelayanan dan kemampuan pendidikan, baik pemerataan, bobot, relevansi dan efisiensi pendidikan. Desentralisasi tidak hanya menampilkan pemerintah nasional membentuk manajemen pendidikan yang terdesentralisasi, memisahkan juga memerankan penggerak bagi kalangan untuk memajukan manajemen pendidikan yang berkualitas. Adapun yang dimaksud atas desentralisasi manajemen pendidikan adalah penyerahan kekuasaan dari pemerintah pusat mendapatkan area untuk melakukan ketentuan manajemen dan membentuk perencanaan seorang diri berkualitas menangani masalah pendidikan serta mengacu pada sistem pendidikan nasional. 


\section{Cara Memanajemen Sekolah yang Bermutu}

Berbagai jenis lembaga pendidikan Islam yang ada, kelihatannya belum membuktikan perbaikan mutu pendididkan Manajemen atau penyelenggaraan membentuk bagian integral yang tidak dapat dipisahkan dari sistem pembelajaran yang dapat diwujudkan sebagai optimal, efektif, dan efesien. Manajemen sekolah bukanlah aktivitas mudah. Sebagai kepala sekolah sekali-sekali kewalahan selama melaksanakan pekerjaannya. Manajemen sekolah yang baik haruslah menyimpan papan penerangan yang bisa diakses oleh siswa dan orangtuanya bila saja dan dari mana saja. Dengan cara ini, orangtua siswa tak perlu lagi datang ke sekolah untuk mencari informasi seputar siswa dan keperluan sekolah lainnya Tak dapat dipungkiri bahwa inventarisasi sekolah sangatlah rentan sarana dan prasarana yang mengalami kerusakan atau hilang. Benda-benda yang ada di sekolah perlu di inventarisir. sebab jika tidak, maka sekolah yang akan menanggung ruginya. Dengan sistem inventaris yang terintegrasi dengan barcode sangatlah mendukung manajemen inventaris sekolah. Dengan sistem inventaris, staf atau guru yang dibertugaskan akan lebih mudah mencatat dan melacak kehadiran dan kondisi inventaris sekolah dengan lebih akurat.

Keberadaan staf yang ada di lingkungan sekolah bukan hanya guru. Ada juga asisten pendidikan, keamanan, laboratorium, dan housekeeping yang bertanggung jawab untuk mengelola data kehadiran, gaji, asuransi, dan pajak setiap karyawan, yang jika dilakukan secara manual akan memakan waktu. Sekolah dan universitas harus mulai menggunakan perangkat lunak bila memungkinkan. Menggunakan perangkat lunak akan membuat administrator sekolah Anda lebih mudah, lebih cepat, dan lebih akurat untuk mengelola guru dan staf. Pengelolaan upah, kehadiran, serta asuransi dan pajak dalam satu platform inilah yang membuat sekolah-sekolah di Indonesia mulai menggunakan software khusus sekolah untuk membantu pengelolaan sekolah. Dengan bantuan software sekolah, tugas-tugas tersebut akan menjadi lebih mudah sehingga kepala sekolah dapat fokus mengembangkan sekolahnya.

Sekolah bermutu harus mengacu kepada SDM yang bermutu, karena akan mampu melaksanakan pengelolaan yang bermutu pula. Pengelolaan dan pelaksanaan yang bermutu akan mampu menyiapkan siswa yang bermutu. Bahasa sederhananya adalah "kualitas manusianya" Beberapa ciri sekolah yang bermutu dapat dikemukakan (1) Berfokus pada pelanggan (2) Memiliki SDM andal (3) Menghindari masalah dan kemelut internal (4) Selalu belajar dari masalah dan kekurangan (5) Pendelegasian tugas dengan baik (6) Memiliki visi, misi, dan tujuan yang jelas (7) visi misi sebagai acuan (8) Prestasi dan kualitas sebagai budaya kerja (9) Selalu mengevaluasi kerja secara teratur (10) Pelaksanaan supervisi yang terprogram (11) Memberikan tindak lanjut (12) Memberikan penghargaan terhadap prestasi yang dicapai siswa atau guru. Pelanggan, ada pelanggan internal dan ada pelanggan eksternal. Pelanggan itu sendiri dapat diterjemahkan orang, atau masyarakat yang membutuhkan atau merasa berkepentingan terhadap sekolah, secara langsung mapun tidak langsung. Contoh sederhana, guru, siswa, orangtua murid, atau masyarakat 
umumnya adalah pelanggan yang perlu dilayani dan dipenuhi kebutuhannya, sesuai keinginannya.

Pelanggan internal seperti guru, siswa, tenaga kependidikan lainnya, jangan dituntut kerja sebelum diberikan pemahaman apa yang seharusnya mereka lakukan. Jangan menuntut kualitas pekerjaan, sebelum mereka memahami apa yang seharusnya dilakukan. Jangan menuntut siswa disiplin, sebelum guru dan Kasek berdisiplin. Soal pelanggan, tidak lepas dari pelayanan dan keinginan. Pelayanan dan keinginan tidak lepas dari hati dan kebutuhan. Tidak ada manusia yang tidak membutuhkan, tidak ada manusia yang tidak memiliki rasa dan keinginan. Bagi Kasek jadilah "pemberi." Pemberian yang sangat berkesan, hatimu. Artinya, tunjukan kebaikanmu pada semua warga sekolah. Jadikan warga sekolah sebagai parnet, pasangan, hindari atasan bawahan Syarat mutlak seorang Kasek melayani pelanggan internal dengan baik adalah "menyatakan," memahami "keinginan," kemudian baru "mendelegasikan" apa yang menjadi keinginan atau tugas masingmasing.

Dalam membaca manajemen pendidikan untuk kiranya kita sangat perlu menangkap fungsi pokok manajemen sebagaimana disebutkan dalam definisi di atas. sekitar fungsi tersebut dapat dideskripsikan sebagai berikut, perencanaan adalah proses memastikan melalui cara atau metode sistematis sehingga dapat mencapai atau menetapkan tujuan. Yang akan dapat membangun kerja sama antara dua pribadi atau lebih dalam sebuah bentuk tertentu untuk mencapai tujuan, dengan maksud da tujuan yang bertentangan sehingga membutuhkan struktur yang bertentangan, yang dapat diupaya penyusunannya secara struktur organisasi melalui suatu desain kebutuhan. bimbingan adalah proses mengarahkan yang dapat menguasai anggota organisasi secara individu maupun keseluruhan dalam pelaksanaan berbagai kegiatan untuk mencapai tujuan. Pengendalian adalah proses yang menjamin atau dapat dipastikan bahwa kegiatan yang dilaksanakan untuk mencapai tujuan serta wajib sesuai dengan program yang telah dibuat. Ketiga faktor penting untuk pengendalian pendidikan adalah standar kinerja, serta pengukuran kinerja yang telah dilaksanakan, dan perbandingan antara kinerja yang telah diterapkan dengan mengacu pada standar kerja. Jika dalam latihan kegiatan maka pemimpin yang dapat dilakukan untu perbaikan untuk menghilangkan atau mengurangi penyimpangan penyimpangan tersebut tersebut.

Berdasarkan paparan mengenai manajemen pendidikan pada, manajemen adalah suatu keharusan yang ada dalam lembaga pendidikan. Jika manajemen dalam sebuah lembaga pendidikan baik maka dapat dipastikan lembaga pendidikan tersebut dapat berkualitas dan bermutu. Untuk peningkatan mutu dalam lembaga pendidikan yang dapat memunculkan sebuah konsep baru dengan manajemen berbasis sekolah sehingga dapat memberikan wewenang kepada sekolah dan guru dalam menata pendidikan dan pengajaran, disebut merencanakan, mengorganisasi, mengawasi, mengendalikan serta dapat mengembankan seluruh pendidikan sebagai sumber daya. 


\section{Konsep Sekolah MBS (Manajemen Berbasis Sekolah)}

Sebagai bentuk sekolah yang berbasis (MBS) yang merupakan bentuk alternatif pengelolaan sekolah dalam rangka desentralisasi pendidikan yang ditandai adanya kewenangan dalam pengambilan keputusan di tingkat sekolah, serta partisipasi masyarakat yang lebih tinggi dalam kerangka kebijakan pendidikan nasional (Sutarto et al., 2014). reformasi pendidikan sekolah dalam menerapkan Manajemen Berbasis Sekolah (MBS) adalah merupakan usaha yang menginginkan perubahan dengan memberikan wewenang kepada sekolah, sehingga menghindarkan format sentralisasi dan birokratisasi yang dapat menyebabkan hilangnya fungsi manajemen sekolah.

Dalam untuk meningkatkan manajemen berbasis sekolah adalah dengan peningkatkan efisiensi, mutu dan pemerataan pendidikan. Untuk meningkatankan efisiensi dapat diperoleh melalui keleluasaan mengelola sumber daya yang ada, partisipasi masyarakat dan penyederhaan birokrasi.

Pelaksanaan Manajemen Berbasis Sekolah yang memegang peranan adalah kepala sekolah sebagai manajer dimana kepala sekolah telah melakukan proses perencanaan, pengorganisasian, menggerakkan, dan mengoordinasikan dalam suatu program sekolah dengan baik.

Kendala-kendala tersebut adalah: 1) analisis kebutuhan untuk penempatan guru dan tenaga kependidikan rendah sesuai dengan apa yang telah dilakukan sebelumnya, 2) beban kerja guru antar guru tidak ada pemerataan, ada yang berlebihan jam mengajarnya, sementara guru lain kurang, 3) kesulitan mencapai guru yang sesuai utamnya pada SMK. Dengan demikian, dapat dirumuskan bahwa Manajemen Berbasis Sekolah (MBS) munculnya beberapa alasan. Pertama, terjadinya kekuasaan dan kewenangan yang terpusat pada atasan yang kurang memperhatikan bawahan. Kedua, kapasitas pendidikan yang kurang baik terlebih cenderung menurun.

Perwujudan dari suatu rangkaian reformasi pendidikan yang ditawarkan MBS kepada sekolah adalah untuk menjadikan pendidikan yang lebih baik dan bermutu membantu bagi para siswa. Otonomi dalam manajemen merupakan potensi bagi sekolah dalam menaikkan kinerja staf yang ditawarkan kepada masyarakat terhadap pendidikan. Kewenangan yang diberikan sekolah yang membentuk inti dari MBS yang dipandang perlu memiliki tingkat efektivitas tinggi serta memberikan beberapa keuntungan adapun Faktor penunjang Efektivitas Manajemen Berbasis Sekolah.

1. Kewenangan dan Otonomi Institusi Sekolah Yang Jelas.

2. Praktek Kepemimpinan Demokratis dan Pengambilan Keputusan Teknis yang Partisipatif di Sekolah.

3. Pemberdayaan prasarana Pendidikan yang Efektif bermutu Mendukung Program Pembelajaran.

\section{Karakteristik Sekolah Berdasarkan Manajemen Sekolah}

Penerapan prinsip-prinsip MBS pada sekolah harus lebih bertanggung jawab (high responsibility), lebih kreatif dalam mengambil tindakan, lebih memiliki kewenangan (more authority), dan dapat dipertanggungjawabkan kepada pihak yang 
berkepentingan/tanggung jawab (stakeholder). Otonomi, fleksibilitas, partisipasi dan inisiatif.

a. Prinsip otonomi

Prinsip otonomi sebagai bentuk pengaturan diri dan pengelolaan diri, serta kemandirian proyek dan investasi, merupakan ukuran utama kemandirian sekolah. Ini memberikan jaminan untuk kelangsungan hidup dan perkembangan sekolah.

b. Prinsip fleksibelitas

Pengelolaan dana yang fleksibel yang diberikan kepada sekolah dapat diartikan sebagai prinsip keluwesan dan prinsip memanfaatkan dan mengalokasikan sumber daya sekolah dengan sebaik-baiknya untuk menaikkan mutu pendidikan sekolah. Prinsip ini dapat mengarahkan kepada sekolah yang lebih baik dalam menyikapi permasalahan dan tanggapan yang harus ditangani.

c. Prinsip partispasi

Menciptakan lingkungan yang bebas dan demokratis agar warga sekolah (guru, siswa) dan seluruh lapisan masyarakat menghargai mereka yang berpartisipasi langsung berisi pengelolaan pendidikan. Dimulai dengan pengutipan keputusan, implementasi, dan penilaian untuk meluaskan kualitas pendidikan. Saya pikir jika seseorang berpartisipasi, staf terkait juga akan memiliki hubungan dengan sekolah. Rasa memiliki", sehingga peserta juga memiliki tanggung jawab untuk memberikan pendidikan yang lebih cerdas.

d. Prinsip-prinsip advokasi

Manusia bukanlah sumber daya yang statis, melainkan konsep dasar sumber daya yang dinamis, sehingga kita harus terus menggali, menemukan dan melebarkan potensi sumber daya manusia untuk mengubahnya menjadi sumber daya yang dapat secara aktif mengelola pendidikan.

\section{Tujuan dan Manfaat Manajemen Berbasis Sekolah}

MBS adalah desentralisasi level otoritas penyelenggaraan sekolah kepada level sekolah (Handoyo et al., 2021). Penerapan model MBS bertujuan untuk meluaskan efisiensi, kualitas dan keadilan pendidikan. Efisiensi terutama berasal dari fleksibilitas penyederhanaan sumber daya pengelolaan untuk partisipasi masyarakat dan karyawan. Dalam rangka penambahan mutu, dapat dicapai melewati peran orang tua di sekolah, fleksibilitas pengelolaan sekolah dan kelas, penambahan profesionalisme guru dan kepala sekolah, serta penerapan sistem motivasi dan insentif. Fitur utamanya adalah meningkatkan kualitas dan meningkatkan peran pendukung masyarakat kepada pemerintah. Perasaan memiliki ketinggian, memberikan masyarakat rasa sekolah yang tinggi (Hidayat \& Machali, 2012). Aplikasi manajemen berbasis sekolah pada dasarnya membagikan banyak manfaat, karena MBS memberikan kebebasan dan keleluasaan yang besar bagi sekolah, serta sarana dan prasarana pendukung. Ia memiliki otonomi, dapat memberikan keleluasaan, dapat lebih meluaskan kesejahteraan guru, sehingga lembaga pendidikan dapat lebih fokus pada pendidikan. Selain itu, pelaksanaan MBS juga dapat menumbuhkan profesionalisme guru dan kepala sekolah menjadi pemimpin sekolah, 
karena konsep MBS mengharuskan guru dan kepala sekolah memiliki kebebasan dan kemandirian dalam penyusunan program dan rencana sekolah. Ada peluang untuk mengembangkan kursus dan rencana untuk guru dan kepala sekolah, tentu saja, pelatihan kursus disesuaikan dengan kebutuhan masyarakat. Meningkatkan dan menjamin pelayanan pendidikan yang sesuai dengan kebutuhan masyarakat dan peserta didik. SBM menekankan partisipasi maksimal semua pihak (seperti sekolah swasta dan sekolah agama) untuk memastikan partisipasi yang lebih luas dari fakultas, staf, orang tua dan siswa dalam pengambilan keputusan pendidikan. Orang tua, siswa, dan seluruh masyarakat membuat keputusan tentang pendidikan bersamasama.

Kontrol dan pengawasan masyarakat serta pemerintah dan pengelola sekolah menjadikan sekolah akuntabel, transparan dan demokratis, sehingga menghilangkan monopoli manajemen pendidikan. Ketika membuat keputusan tentang pendidikan. Kesempatan untuk terlibat ini dapat meluaskan komitmen Anda terhadap sekolah. Kesempatan untuk terlibat ini dapat meningkatkan kewajiban Anda terhadap sekolah. Selain itu, aspek-aspek tersebut pada akhirnya akan membantu efektifitas tujuan sekolah.

\section{Karakteristik Manajemen Sekolah}

Perbaikan sekolah dapat mengoptimalkan kinerjanya melalui peran sekolah yang merupakan ciri khas MBS. Beberapa tolok ukur penilaian meliputi proses pengajaran, pengelolaan sumber belajar, profesionalisme pendidik, dan bentuk pengelolaan secara kelengkapan. Ciri-ciri manajemen mutu sekolah inklusi, yang dapat mencakup unsur-unsur sekolah yang efektif yang dapat dijadikan sebagai input, proses dan output (Sutarto et al., 2014). Secara sistematis, berlaku untuk semua aspek pendidikan. Analisis ketiganya bisa dimulai dari awal. Selesaikan dengan masukan. Dengan cara ini, kinerja sekolah dapat diukur dengan kinerja sekolah itu sendiri, yaitu prestasi atau prestasi yang dihasilkan dalam proses sekolah. Karakteristik dasar MBS adalah sekolah memiliki kebebasan, tingkat partisipasi masyarakat yang tinggi dan peran orang tua, pemimpin sekolah yang demokratis dan profesional beserta kerjasama tim yang profesional.

a) Memberi sekolah otonomi yang luas

Menerapkan tanggung jawab sumber daya, menyesuaikan tindakan dengan kondisi lokal, memberdayakan sekolah, dan memungkinkan pendidik untuk lebih fokus pada tugas utama mereka. Dalam hal ini, sekolah menjadi lembaga pendidikan diberikan kewenangan dan kewenangan yang luas perlu merumuskan mata kuliah dan rencana pembelajaran sesuai dengan suasana dan kebutuhan peserta didik dan masyarakat.

b) Keterlibatan Masyarakat Dan Orang Tua

Program yang didukung oleh tingginya kerja sama orang tua dan masyarakat tidak hanya menjunjung sekolah melalui bantuan dana, tetapi juga mengembangkan dan memajukan program-program yang berhasil meluaskan kualitas sekolah menjalankan komite sekolah dan komite pendidikan. Masyarakat 
bekerjasama dengan orang tua untuk mendirikan dan membantu sekolah sebagai konsultan beragam pekerjaan sekolah untuk meningkatkan kualitas penerimaan.

c) Kepemimpinan yang demokratis dan ahli

Tanpa kepemimpinan kepala sekolah yang demokratis dan profesional, program pelibatan masyarakat di sekolah tidak dapat berjalan dengan lancar. Bakat dengan kemampuan dan etika profesional adalah pelaksana utama proyek sekolah. Kepala sekolah adalah seorang administrator sekolah yang diangkat melalui komite sekolah dan mengelola semua kegiatan sekolah sesuai dengan kebijakan yang telah ditetapkan. Sekolah mempekerjakan guru sebagai pendidik profesional di bidangnya masing-masing, sehingga kepala sekolah dan guru dapat bekerja sama sesuai model kinerja profesional yang disepakati bersama untuk memberikan kemudahan dan dukungan bagi kesuksesan pembelajaran. Dalam pengutipan keputusan, direktur menerapkan prosedur bottom-up, yaitu memperhatikan bawahan secara demokratis dan meminta pertanggungjawaban semua pihak atas keputusan yang dibuat dan pelaksanaannya.

d) Kerjasama tim yang erat dan terbuka

Adanya tim yang kompak dalam merumuskan kurikulum sekolah dapat memasang apakah sekolah dapat berhasil mencapai tujuan pendidikan. Semua pihak ikut serta dalam terselenggaranya manajemen pendidikan yang harmonis dan sama-sama membutuhkan. Oleh karena itu, keberhasilan MBS merupakan hasil dari sinergi kerjasama tim (sinergi) yang erat dan transparan. Menurut (Bafadal, 2003).

\section{Manajemen Berbasis Sekolah Sebagai Proses Pemberdayaan}

Pemberdayaan dalam pendidikan membentuk cara yang sangat praktis dan produktif. Proses terbaik dan paling efektif adalah dengan mengalokasikan tugas kepada guru secara proporsional, dalam proses ini Keputusan dan tanggung jawab. Dalam MBS sendiri, pemberdayaan bertujuan untuk meningkatkan kinerja sekolah agar optimal, efektif dan efisien. Di sisi lain, perhatian juga harus diberikan pada pemberdayaan siswa dan komunitas sekolah. Sebagai proses pemberdayaan, MBS membuat cara untuk merangsang potensi dan kemampuan siswa dalam mengendalikan diri dan lingkungan, yang dapat digunakan untuk meningkatkan kesejahteraan (Syahru, 2017).

\section{Pendidikan Sekolah Islam}

Madrasah berasal dari bahasa Arab, dari kata "Darasa Yadrusu Darsan Madrasatan" yang artinya belajar. Tata bahasa Arab dari kata madrasah adalah dharafeat yang berarti gambaran suatu daerah, dalam hal ini madrasah bermanfaat untuk tempat belajar. Terjemahan bahasa Indonesianya berarti "madrasah", yang berarti "sekolah". Tidak ada perbedaan antara madrasah dan sekolah dalam hal apa yang secara teknis formal dalam proses pembelajaran, tetapi madrasah di Indonesia bukan dapat dipahami sebagai sekolah, tetapi diberi konotasi yang makin spesifik, yaitu "sekolah agama" dimana siswa keluar masuk Belajar keluar hanya dalam Islam. Sebagai lembaga pendidikan Islam madrasah, Indonesia kini telah menjadi bagian 
dari budaya. Maraknya pesantren menjadi lembaga pendidikan di Indonesia telah berlebihan memberikan coretan sejarah dari zaman penjajahan Belanda hingga saat ini.

Berikut ini secara singkat memperkenalkan sejarah perkembangan sekolah agama di Indonesia. Faktor penting di balik kebangkitan sekolah Islam adalah bahwa orang percaya bahwa sistem pendidikan Islam tradisional tidak dapat memenuhi keinginan yang sebenarnya. Dan Kecepatan Perkembangan Sekolah (Aziz, 2015) 88 Volume VIII No 1 Tahun 2015.

Munculnya pemikiran sekuler di masyarakat, dalam perkembangan sekularisme, kaum reformis memasukkan pendidikan Islam di sekolah. Di masa sistem lama, orang mencoba meniadakan dua sistem pendidikan. Mencoba menghapusnya, melakukan tiga upaya. Pertama, pendidikan Islam dimasukkan ke dalam kurikulum pendidikan umum sekolah negeri dan swasta melalui studi agama. Kedua, mengintegrasikan ilmu umum ke dalam kurikulum pendidikan madrasah. Ketiga, mendirikan sekolah pelatihan guru agama (PGA) perlu melatih guru agama untuk sekolah umum dan sekolah agama. Awal pemerintahan sistem baru Tahun (1966).

Sistem pendidikan akhirnya menghasilkan dua landasan garis utama, yaitu kekuasaan Islam dan nasionalisme. Pemerintah Indonesia berusaha untuk tidak menolaknya dengan ideologi Pancasila. Awalnya, pemerintah Orde Baru tidak mendukung sekolah agama secara legal formal. Pada tahun 1972 dan pada masa Orde Baru, Presiden Suharto mengeluarkan Keputusan Presiden Nomor 34 Tahun 1972 (Keppres) untuk mengelola sekolah agama di bawah arahan Menteri Pendidikan dan Kebudayaan (Mendikbud). Kebijakan ini dianggap sebagai upaya sekuler. Untuk menghilangkan madrasah dari sistem pendidikan Indonesia, respon ini mendorong pemerintah untuk menghasilkan keputusan bersama antara Menteri Pendidikan dan Kebudayaan (Mendikbud), Menteri Agama (Menag) dan Menteri Dalam Negeri. Isinya membalikkan status sekolah agama di bawah administrasi agama, tetapi harus membawa kurikulum yang ditentukan oleh pemerintah.

Di era pembaruan, dengan berlakunya Undang-Undang Nomor 20 Tahun 2003 tentang Sistem Pendidikan Nasional, pendidikan Islam menjadi salah satu simbol pendidikan nasional. Lembaga pendidikan Islam yang menyimpan harapan yang sangat besar untuk bertambah dan membesar, menyertai kontribusinya terhadap pengembangan pendidikan nasional. Di bawah arahan Kementerian Agama, Madrasah telah menjadi bagian internal dari sistem pendidikan nasional. Hal ini bertepatan dengan berlakunya Undang-Undang Nomor 20 Sistem Pendidikan Nasional Tahun 2003, yang menggantikan Undang-Undang Nomor 2 Tahun 1989. Madrasah yang bergantung pada Departemen Agama berarti madrasah harus dikelola secara terpusat. Artinya, kekuasaan umum adalah milik pemerintah pusat. Tentu saja, ini memiliki pro dan kontra. Namun, dilihat dari permasalahan sekolah agama tersebut di atas, sekolah harus melayani sistem pendidikan desentralisasi atas 
mengambil manajemen berbasis sekolah sebagai rencana manajemen pendidikan sekolah.

\section{Manajemen berbasis sekolah sebagai peningkatan mutu pendidikan madrasah}

Pada umumnya setiap lembaga pendidikan memegang tujuan simpulan yang diharapkan. Tujuan akhir dari adalah untuk meningkatkan kualitas, yaitu tingkat keunggulan sekolah, tingkat di mana sekolah yang bersaing dengan sekolah lain memiliki keunggulan komparatif (Nurokhim, 2017). Sekolah kelas satu berkualitas tinggi. Kualitas merupakan peluang untuk memenangkan hadiah yang sangat berharga, sehingga penampilan para pesaing merupakan tantangan untuk meningkatkan kualitas sekolah. Untuk mewujudkan pendidikan yang sesuai standar mutu, sebagai bagian dari guru dan pendidik, penting untuk bersandar pada Peraturan Pemerintah No. 19 Republik Indonesia tentang Standar Nasional Pendidikan. Standar nasional pendidikan meliputi: Standar Isi, Standar Keterampilan Lulusan, Standar Pendidik dan Pendidik, Standar Sarana dan Prasarana, Standar Manajemen, Standar Pendanaan, serta normal Penilaian Pendidikan.

Kualitas pendidikan sebelumnya menunjukkan pentingnya sekolah agama sebagai aktor otonom utama, serta tugas orang tua dan masyarakat. Kegiatan dan perkembangan pendidikan, termasuk kegiatan yang berkaitan dengan pendidikan, sebagian besar ditentukan bukan oleh pihak selain madrasah, tetapi oleh interaksi antara madrasah yang berkepentingan dengan pelanggan. Sebagai unit pelaksana utama pendidikan formal, sekolah memiliki kondisi lingkungan yang beragam, penuh vitalitas dan kreativitas, dan sekolah harus berupaya meningkatkan kualitas pendidikan dalam pekerjaannya. Jika madrasah Memberikan rasa percaya diri, menata dan merawat diri bertemu menjalani kondisi lingkungan dan kebutuhan masyarakat. Konsep ideologis ini menyebabkan munculnya metode baru, yaitu pengelolaan peningkatan mutu pendidikan dengan sekolah agama sebagai lembaga primer. Metode ini disebut manajemen peningkatan mutu pendidikan berbasis madrasah (Suryosubroto, 2009). Intinya, Manajemen Berbasis Madrasah (MBM) di Sekolah Madrasah memberikan rencana dan layanan kemajuan kepada siswa, orang tua, dan masyarakat.

Berdasarkan fungsi dan manfaat tata usaha berbasis madrasah, jika madrasah menerapkan manajemen mutu madrasah untuk meluaskan mutu pendidikan madrasah, maka mewujudkan salah langkah. Apalagi jika ditelaah berbagai masalah, khususnya masalah madrasah, berisi hal pembedaan dan pemerataan pendidikan di lembaga pendidikan Islam. Penulis berpendapat bahwa organisasi sekolah terpusat seharusnya bukan memungkinkan sekolah untuk menerapkan rencana manajemen berbasis sekolah. Dalam hal ini madrasah tetap berhasil melaksanakan manajemen berbasis sekolah, yang akan datang menjadi manajemen madrasah.

\section{Kesimpulan}

Manajemen berbasis sekolah atau school based management adalah dasar manajemen untuk pengembangan mutu pendidikan di era otonomi daerah. Pasca 
diundangkannya UU Otonomi Daerah, MBS mempengaruhi pelaksanaan manajemen sekolah di bidang pendidikan. Ketentuan lain dari MBS adalah bahwa departemen administrasi dapat memberikan otonomi untuk sekolah dan meluaskan sekolah akan membuat ketentuan umum untuk mencapai target mutu sekolah berisi rangka pendidikan.

Pada hakekatnya konsepsi manajemen berbasis sekolah ini dapat diterapkan pada madrasah, yang akan datang menjadi istilah Manajemen Mutu Berbasis Madrasah (MMBM). Penerapan administrasi pengembangan nilai berbasis madrasah harus dapat dijadikan sebagai jalan atas beragam jenis permasalahan yang dihadapi madrasah. Dari segi penelitian, pengarang merasa nilai madrasah masih rendah, hal ini disebabkan adanya diskriminasi, birokrasi dan pusat pengelolaan pendidikan madrasah, serta pengaruh pengambil kebijakan dalam pengambilan keputusan dan ketidaksesuaian. meningkatkan kualitas sekolah Islam. Antara sekolah agama, negara dan masyarakat. melihat beragam permasalahan yang dihadapi sekolah, hingga manajemen peningkatan mutu berbasis sekolah yang dilaksanakan oleh sekolah dapat lanjut bermakna di bawah kendali dan kendali pemerintah pusat, sehingga tercapai target pendidikan sekolah. misalnya begini, sekolah Islam akan menjadi Islam yang berkualitas dan bertanggung jawab. Institusi pendidikan 


\section{BIBLIOGRAFI}

Arikunto, S. (2010). Prosedur Penelitian: Suatu Pendekatan Praktik (Edisi Revisi). Jakarta: Rineka Cipta. Jurnal Ilmiah Farmasi Farmasyifa. Https://Doi. Org/10.29313/Jiff. V1i1, 2873. Google Scholar

Aziz, A. Z. (2015). Manajemen Berbasis Sekolah: Alternatif Peningkatan Mutu Pendidikan Madrasah. El Tarbawi, 8 (1), 69-92. Google Scholar

Bafadal, I. (2003). Manajemen Peningkatan Mutu Sekolah Dasar Dari Sentralisasi Menuju Desentralisasi. Jakarta: Bumi Aksara. Google Scholar

Chan, S. M., \& Sam, T. T. (2007). Analisis SWOT Kebijakan Pendidikan Era Otonomi Daerah [SWOT Analysis Of Educational Policy In The Era Of Regional Autonomy]. Jakarta, Indonesia: Penerbit PT Rajagrafindo Persada. Google Scholar

Djalal, F. (2011). Panduan Pendidikan karakter. Jakarta: Kementerian Pendidikan Nasional (Balitbangkur). Panduan Pendidikan Karakter. Jakarta: Kementerian Pendidikan Nasional (Balitbangkur). Google Scholar

Firdianti, A. (2018). Implementasi Manajemen Berbasis Sekolah Dalam Meningkatkan Prestasi Belajar Siswa. Gre Publishing. Google Scholar

Handoyo, K., Mudhofir, M., \& Maslamah, M. (2021). Implementasi Manajemen Berbasis Madrasah Dalam Peningkatan Mutu Pendidikan Di Madrasah. Jurnal Ilmiah Ekonomi Islam, 7 (1), 321-332. Google Scholar

Hasanah, D. S., Fattah, N., \& Prihatin, E. (2010). Pengaruh Pendidikan Latihan (Diklat) kepemimpinan guru dan iklim kerja terhadap kinerja guru sekolah dasar se Kecamatan Babakancikao Kabupaten Purwakarta. Jurnal Penelitian Pendidikan, 11 (2), 90-105. Google Scholar

Hidayat, A., \& Machali, I. (2012). Pengelolaan Pendidikan: Konsep, Prinsip, Dan Aplikasi Dalam Mengelola Sekolah Dan Madrasah. Kaukaba. Google Scholar

HM, M. A. (2018). Manajemen Berbasis Sekolah (Alternatif Peningkatan Mutu Pendidikan Madrasah). Ekspose: Jurnal Penelitian Hukum Dan Pendidikan, 17 (2), 601-614. Google Scholar

Nugroho, R. (2008). Kebijakan pendidikan yang unggul: kasus pembangunan pendidikan di Kabupaten Jembrana 2000-2006. Pustaka Pelajar. Google Scholar

Nurokhim, N. (2017). Manajemen Berbasis Sekolah: Solusi Peningkatan Mutu Pendidikan Madrasah. Jurnal Kependidikan, 5 (2), 247-260. Google Scholar

Ramadhan, M. A., \& Sugiyono, S. (2015). Pengembangan Sumber Dana Sekolah Pada Sekolah Menengah Kejuruan. Jurnal Pendidikan Vokasi, 5 (3), 340-351. Google Scholar 
Riant, N. (2008). Kebijakan Pendidikan Yang Unggul. Yogyakarta: Pustaka Pelajar. Google Scholar

Suryosubroto, B. (2009). Manajemen pendidikan di sekolah. Rineka Cipta. Google Scholar

Sutarto, M., Darmansyah, D., \& Warsono, S. (2014). Manajemen berbasis sekolah. The Manager Review Jurnal Ilmiah Manajemen, 13 (3), 343-355. Google Scholar

Syahru, R. A. (2017). Penerapan Manajemen Berbasis Sekolah dalam Pemberdayaan Potensi Guru di SMA Negeri 4 Bulukumba. Universitas Islam Negeri Alauddin Makassar. Google Scholar

Copyright holder:

Muh Anwar (2021)

First publication right:

Jurnal Syntax Admiration

This article is licensed under:

(c) (i) (?) 